\title{
IAMJ
}

INTERNATIONAL

AYURVEDIC

MEDICAL JOURNAL

Research Article

ISSN: 2320-5091

Impact Factor: 6.719

\section{INDIAN PLASTERING TECHNIQUE IN MALLEOLAR FRACTURES}

\author{
Ashik Narayan $\mathbf{S}^{1}$, Rejani $\mathbf{H}^{2}$ \\ ${ }^{1}$ Final Year P.G. Scholar, ${ }^{2}$ Professor \\ Department of Shalyatantra \\ Vaidyaratnam P. S. Varier Ayurveda College, Kottakkal, Kerala, India
}

Corresponding Author: ashiknarayan@gmail.com

https://doi.org/10.46607/iamj0208122020

(Published online: December 2020)

Open Access

(C) International Ayurvedic Medical Journal, India 2020

Article Received: 02/11/2020 - Peer Reviewed: 08/11/2020 - Accepted for Publication: 18/11/2020

Check for updates

\begin{abstract}
Ankle is the most common site where a lower limb fracture can occur. Ankle joint fracture can occur during sports activities and misstep on daily routine. Ankle joint fracture caused by an indirect trauma is about $9 \%$ of all other fractures. As far as the modern conservative management is concerned, a below knee plaster for a period of 3-6 weeks is sufficient enough to protect the fractured ankle joint without displacement. This type of plastering technique may cause some complications like muscle atrophy, cartilage degeneration, and a stiff, painful and swollen joint. Hence, an Ayurvedic approach is relevant in the management of ankle joint fractures. In Ayurveda, ankle joint fracture is termed as Gulphasandhi Bhagna. According to Susruta, initially a fractured ankle joint has to be reduced and then Bandhana should be done along with splint to prevent the movements of fractured fragments which is known as Kuśa Bandhana. There is another modified form of bandaging which is in practice over Southern parts of India and is conventionally known as Indian plaster. It is found to be very effective in the management of ankle joint fractures. It may be understood that it offers an optimal immobilisation. Even though splint bandage is the widely practised method, it has certain disadvantages. It may cause delay in healing. It requires the patient to tend more frequent hospital visits. Hence it is proposed to find out the efficacy of Indian plaster in malleolar fractures. A total number of 20 participants with malleolar fracture were selected and evaluated, by taking detailed history and clinical examination. The study was conducted at Shalyatantra OPD of V.P.S.V. Ayurveda college, Kottakkal. Indian plastering was done on $0^{\text {th }}, 14^{\text {th }}$ and $28^{\text {th }}$ days and retained up to $42^{\text {nd }}$ day. The duration of the treatment was 42 days and follow up was done for 4 weeks after the intervention. Assessment was done on $0^{\text {th }}, 14^{\text {th }}$,
\end{abstract}


$28^{\text {th }}$ and $42^{\text {nd }}$ day for pain, tenderness, stiffness. Radiological assessment was done on $0^{\text {th }}, 28^{\text {th }}$ and $42^{\text {nd }}$ day. The results were analysed statistically. On statistical analysis, it was found that the Indian plaster shows $77.74 \%$ of the efficacy.

Keywords: Malleolar fracture, Gulpha Sandhi Bhagna, Kuśa Bandhana, Indian plaster.

\section{INTRODUCTION}

Ankle fracture is one of the commonest fractures occurring in the lower limb. The incidence of ankle fractures is approximately 187 fractures per 100,000 people each year. ${ }^{1}$ Ankle joint fracture caused by an indirect trauma is about $9 \%$ of all other fractures. There has been an increase in the prevalence of such fractures over the last two decades both in the young and the elderly. Since the mid-1900s, this rate has increased significantly in many industrialized countries, most likely due to growth in the number of people involved in athletics and in the size of the elderly population. ${ }^{2}$ An ankle joint is composed of 3 bones namely talus, tibia and fibula. Most of the ankle joint fractures involve either lateral malleolus or the medial malleolus or both the malleoli together with or without subluxation of talus from its normal position within the tibio-fibular mortise. The vast majority of ankle fractures are malleolar fractures: 60 to 70 percent occur as uni-malleolar fractures, 15 to 20 percent as bimalleolar fractures, and 7 to 12 percent as tri-malleolar fractures. ${ }^{2}$ The overall fracture rates between men and women are statistically similar, although, a higher rate is seen in males in a younger age group, and in the age group of 50 to 70 years in females. ${ }^{2}$ A broken ankle shows the symptoms like pain, swelling, bruising, tenderness, difficulty in walking and weight bearing. Sir Robert Jones said "Ankle is the most injured joint of the body but the least well treated". ${ }^{3}$ Ankle injuries gain importance because body weight is transmitted through it and locomotion depends upon the stability of this joint. They are usually mixed injuries of both ligaments and bones. Each injury is an end result of the sequence of ligamentous and bony failure due to deforming forces. As far as the modern management is concerned a below knee walking plaster for a period of 3-6 weeks will be sufficient enough to protect the fractured ankle joint without displacement. But this type of plastering technique may cause some complications like muscle atrophy, cartilage degeneration, and a stiff, painful and swollen joint. ${ }^{4}$ Hence, Ayurvedic approach is relevant in the management of ankle joint fractures. In Ayurveda, fracture is termed as Bhagna. It is classified into Sandhimukta and Kändabhagna. ${ }^{5}$ There is a specific management protocol for different Bhagna in Āyurvedic texts, which is practiced nowadays. Ācārya Suśruta explained Sthāpana upāya, which include Ancana, Pìdana, Sankssepa and Bandhana. ${ }^{6}$ Anchana is achieved by giving traction and counter traction, then by Pldana proper alignment of the fracture fragments are achieved. Then the properly reduced fracture is immobilized with a technique known as Bandhana (bandaging). To maintain the reduced position, Kuśa (splints) should be placed over the part in such a way that it will prevent further displacement of the fracture fragments. Ācārya Suśruta used the term Gulphasandhi Bhagna to explain ankle joint fractures and emphasised the importance of Bandhana (bandaging) in its management. The traditionally practiced Kuśa Bandhana was eventually developed into conventional splint bandage technique. In Ankle joint fractures, even after reduction the chance of displacement is high. Ayurvedic splint bandaging sometimes fails to provide an effective immobilisation in the optimum level especially in fractures of weight bearing joint. Plaster of Paris used as an immobilisation method in modern system also has complications due to 42 days of continuous immobilisation. So, it is relevant to search for an immobilisation technique which may provide better outcome. There is another modified form of bandaging which is in practice over Southern parts of India and is conventionally known as Indian plaster. ${ }^{7}$ It is found to be very effective in the management of ankle joint fractures. Indian plaster is made by mixing 
black gram powder with white part of egg and is uniformly pasted over the cloth. It may be understood that it offers an optimal immobilisation. Even though splint bandage is the widely practiced method, it has certain disadvantages. It may cause delay in healing. It requires the patient to tend more frequent hospital visits. Hence it is proposed to identify the efficacy of Indian plaster.

\section{Methodology}

Study setting was Shalyatantra OPD of VPSV Ayurveda college, Kottakkal. 20 participants satisfying diagnostic, inclusion, and exclusion criteria were selected for the study.

\section{Diagnostic criteria}

- Radiological assessment

- Clinical signs and symptoms

a. Ottawa ankle rules, b. Pain, c. Swelling., d. Stiffness

\section{Inclusion criteria}

- Patients within the age group 21-45 irrespective of gender.

- Radiologically diagnosed fractures of either Lateral malleolus or Medial malleolus.

\section{Exclusion criteria}

- Pathological fractures

- Open fractures

- Bi-malleolar \& Tri-malleolar fractures

- Fracture along with dislocation

- Pregnant women

- Those who are under prolonged medication for chronic diseases

Intervention (Application of Indian plaster)

Internally: Mustādi marma kașāyam-90 ml twice daily, Gandha tailam - 10 drops once in a day
A. Preparation of Indian plaster $-4 \mathrm{~m} \times 18 \mathrm{~cm}$

White part of egg $\quad-75 \mathrm{ml}$

Black gram powder $\quad-150 \mathrm{gm}$

Indian Plaster was made by mixing black gram powder $(150 \mathrm{gm})$ with white part of egg $(75 \mathrm{ml})$ and it was uniformly pasted over the cloth and kept ready for application.

\section{B. Application of Indian plaster}

Cotton pad $-30 \mathrm{~cm}$ x $25 \mathrm{~cm}$ x $0.5 \mathrm{~cm}$

Splints - (3) $-18 \mathrm{~cm} \times 2.5 \mathrm{~cm} \times 0.4 \mathrm{~cm}$

Splint $\quad$ - (1) $-18 \mathrm{~cm} \times 4.5 \mathrm{~cm} \times 0.4 \mathrm{~cm}$

Participants satisfying diagnostic, inclusion, and exclusion criteria were selected and after closed manipulative reduction, the affected part was applied with Murivenna and a cotton pad of thickness $0.4 \mathrm{~cm}$ was placed over it. Then the splints made out of bamboo in the size described was well covered with a cotton pad and placed on the medial, lateral and posterior aspects of the ankle joint. Another splint was placed on the plantar aspect of the foot. Indian plaster was applied over these. Application of Indian plaster was repeated at an interval of 2 weeks. On $14^{\text {th }}$ day, plaster was cut open using plaster cutting scissors and then observed for any sort of displacement. In doubtful cases of displacement, X-ray was suggested and correction was done if necessary. Then the Indian plaster was applied again. The same was repeated on $28^{\text {th }}$ day and the Indian plaster was removed completely on $42^{\text {nd }}$ day.

- Assessments of pain, tenderness, stiffness were done on $0^{\text {th }}, 14^{\text {th }}, 28^{\text {th }}$ and $42^{\text {nd }}$ day.

- Radiological assessment and grading were done on $0^{\text {th }}, 28^{\text {th }}$ and $42^{\text {nd }}$ day.

- Follow up was done for a further period of 28 days.

\section{Observation and Analysis}

Table 1: Data obtained after statistical analysis

\begin{tabular}{|l|l|l|l|l|l|l|l|l|}
\hline Variables & D0 & D14 & D28 & \multicolumn{3}{l|}{ D42 } \\
& Mean \pm SD & P value & Mean \pm SD & P value & Mean \pm SD & P value & Mean \pm SD & P value \\
\hline PAIN & $4.7 \pm 0.47$ & $<0.001$ & $2.85 \pm 0.59$ & $<0.001$ & $1.45 \pm 0.69$ & $<0.001$ & $1.05 \pm 0.22$ & $<0.001$ \\
\hline TENDERNESS & $5 \pm 0$ & $<0.001$ & $3.05 \pm 0.69$ & $<0.001$ & $1.35 \pm 0.49$ & $<0.001$ & $1 \pm 0$ & $<0.001$ \\
\hline STIFFNESS & $1.05 \pm 0.22$ & $<0.001$ & $1.95 \pm 0.22$ & $<0.001$ & $2 \pm 0.32$ & $<0.001$ & $1.7 \pm 0.47$ & $<0.001$ \\
\hline
\end{tabular}


Table 2: Data obtained after statistical analysis on Healing

\begin{tabular}{|l|l|l|l|l|l|l|}
\hline Variable & D0 & D28 & D42 & \\
\hline & Mean \pm SD & P value & Mean \pm SD & P value & Mean \pm SD & P value \\
\hline HEALING & $1 \pm 0$ & $<0.001$ & $3.35 \pm 0.59$ & $<0.001$ & $4 \pm 0$ & $<0.001$ \\
\hline
\end{tabular}

Figure 1: Effect of Indian plaster

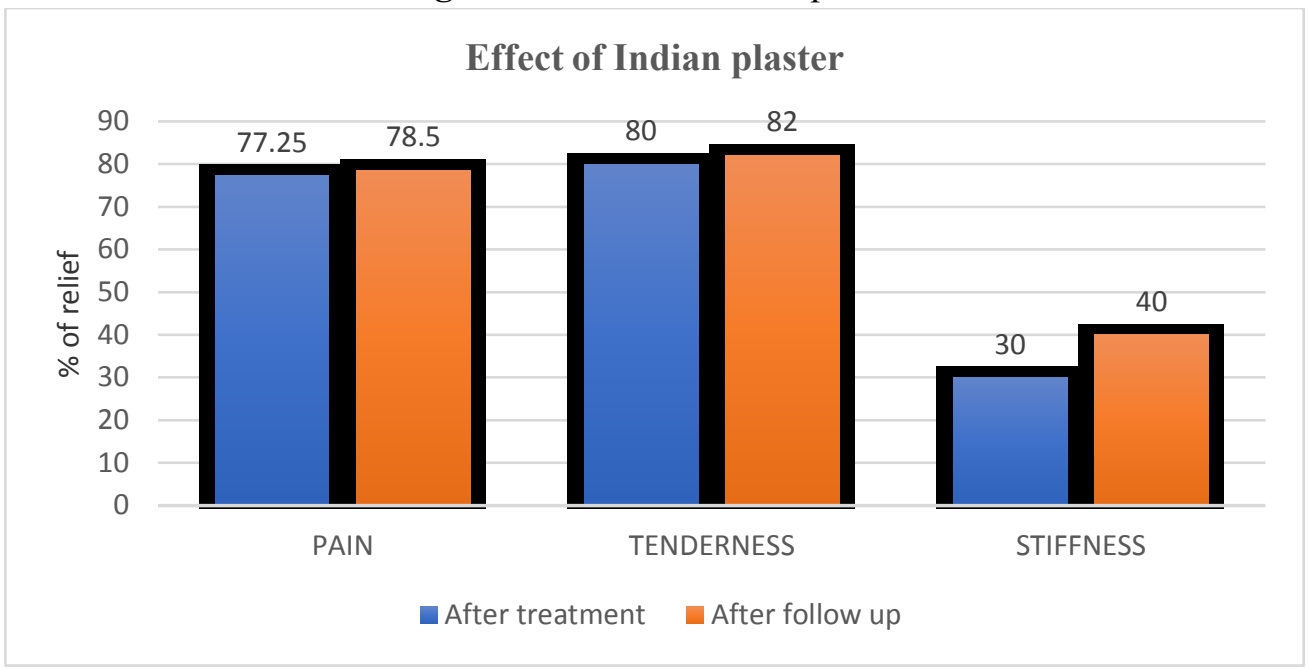

\section{DISCUSSION}

A proper anatomical knowledge is the key stone of success in the management of orthopaedic conditions. Suśruta, while describing the anatomy in Särīrastāna considered Gulpha Pradeśa as both Sandhi and Marma. Gulpha Sandhi Marma is the place, where involves a complexity of many structures like peroneal nerve, tibial artery, fibular artery etc. Injury to the peroneal nerve may result in foot drop and other complications. Many times, an injury to malleolar region causes an excruciating pain. Acharyas have almost similar opinion regarding the Gulpha Marma Viddha Lakșana. This includes Ruja (severe pain), Stambha (restricted movement) and Khañajata (limping). ${ }^{8}$ In the present study it was observed that, $62 \%$ of the participants were developed excruciating pain after injury which is a cardinal feature of Gulpha marma vidtha lakșana. In a previous study conducted by Vipin et al. noted that $40 \%$ of participants had severe Stambha. In the present study 55\% experienced severe Stambha after the injury. ${ }^{9}$ Regarding Khañajata, the present study shows $60 \%$ of participants had severe Khañajata. According to Vipin et al. it was $25 \%$. From these results it is evident that there is a clear association between Gulpha marma kșata and malleolar fractures.
While considering Gulpha pradeśa as Sandhi, common Sandhi Kșata Lakshana explained by Suśruta can be incorporated. The Lakșana of Sandhi Kșata as increased swelling, severe pain, splitting type of pain in the small joints, loss of strength, oedema, loss of function of joints. In the present study most of the participants had these Lakșana, so it can be understood that Sandhi Kșata Lakșana can also be used as a diagnostic tool. ${ }^{10}$

In the present clinical study $65 \%$ of the participants developed malleolar fracture from a bending force. Malleolar fracture usually occurs by a bending force. ${ }^{11}$ Fracture pain is the most common problem caused by bone injury. Immediately after the fracture mechanosensitive nerves that innervate bone gets distorted. Many of the mechano-sensitive nerve fibres are located in the periosteum of the bone ${ }^{12}$. After this, the nerve fibres pass signal to brain resulting in sharp cutting pain. After a few minutes neurotransmitters, cytokines, nerve growth factor (NGF) were released by cells at the fracture site. This stimulate the ectopic nerve sprouting of the sensory and sympathetic nerve fibres which drive sharp cutting pain upon movement and a dull aching pain at rest. Indian plaster provides adequate immobilisation which had an important role in the reduction of pain. Adequate immobilization helps to 
prevent the unwanted movement of bone in and around the area. This helps to reduce the sharp cutting pain due to movement. It indicates that 14 days of immobilization by Indian plaster was more efficacious in reduction of pain in malleolar fractures as it is occurring in a weight bearing joint. Apart from bone injury, soft tissue injury also occurs in a fracture. ${ }^{12}$ This is a bursting type of pain developed as a result of initial inflammatory response. In the present study Murivenna was used as an external application that helps to reduce the inflammation. Murivenna contains coconut oil. This helps to induce the initial vasoconstriction immediately and helps to reduce the initial pain. Mustādi Marma Kașāyam administered internally is a good anti-inflammatory medicine. ${ }^{13}$ It helps to modulate the inflammatory process and thus reducing the pain.

Unlike skin, where non-use promote healing, effective healing of a load bearing bone demands the patient to move, use the injured bone. The most common reason that many participants cannot fully participate in this rehabilitation is due to fracture pain. In the present clinical study, it was found to be effective in reducing pain in the $28^{\text {th }}$ day itself. It was found that participants can walk with this plaster after the reduction of pain. It won't get loosen after walking. When compared to POP it is having less weight. Plaster of Paris may create complications like stiffness, muscle atrophy, vascular degeneration. Sometimes, early mobilisation may cause displacement of fragments. In the present study it was found that early strict immobilisation gives enough stability. This helps in healing and prevention from further displacement. In later stages movement will enhance the healing. This helps in functional healing which considered as gold standard in fracture management. Indian plaster provides adequate immobilisation thus gives an appropriate environment for healing. Fourteen days continuous immobilisation helped in formation of haematoma; this triggered the healing. After the initial phase of strict immobilization pain subsides. Then participants were advised to do non weight bearing exercise. This functional healing promotes bone healing as well as soft tissue healing.

\section{Indian Plaster}

Regarding plastering technique in Ayurveda, Yogaratnākara was the first author mentioned it. ${ }^{14}$ As a first aid, he advised to sprinkle cold water over the injured area and then a layer of mud should be applied immediately after the injury. This is a very primitive form of plaster. In a previous study conducted by Saifudheen et al. egg white was used for mixing the medicine. ${ }^{15}$ According to Dudhmal et al. water can be added but it may be subjected to heat up to the evaporation of water content. ${ }^{16}$ This clearly indicates that no water content should remain after the preparation of Indian plaster. It was found that any water content added to this will create fungus and produce foul smell. After the administration also this should be followed. So, it is better to instruct the patient not to allow water content to touch the plaster surface. Egg white used in the present study, helped to mix the black gram powder and maintain its semi fluid consistency. According to Radhakrishnan et al. egg white was an inevitable compound in the plastering technique of houses in ancient India which gives the strength and stability after drying. ${ }^{17}$ Usually seed of vegetables and pulses were used as a binding agent at that time. So due to availability and cost effectivity black gram was selected to meet the purpose. The Kora cloth used for the study was having adequate tensile strength and sufficient to provide adequate immobilization. Cotton wool was used as a padding material provides a buffering medium between skin and cloth. It also helps in retention of Murivenna which was used as an external medicine on the injured part. Thickness of the cotton wool can be increased that ensures the retention of sufficient quantity of oil on the affected part. It also helps in maintaining the tightness of plaster after the reduction of initial swelling. It was found that an extra cotton pad of $5 \mathrm{~mm}$ thickness can be added. This will occupy the space formed after the reduction of swelling. In the present study it was found that adequate thickness of cotton helps preventing the complication like skin irritation, blisters, compression wound. In the present study $90 \%$ of the participants didn't developed any complications, 10\% participants had developed itching after 14 days. But an additional 
layer of cotton pad helped to prevent this complication in later sittings. Splints are used to prevent redisplacement of fractured fragments. In the present study bamboo splints were used. Bamboo is strong and can easily made into the form of splints. During the study it was found that even after the application of great force splints never got broken. In the present study, none of the participants had experienced any issue regarding the breaking of splints. This shows its stability when used as splints in fracture management. It also found to be malleable at some extent, helps to allow weight-bearing exercise which was done after the reduction of pain. It won't create any injury to the affected part due to its malleability. At the same time in case of an internal fixation, it may create wound when exposed to heat. Moreover, it may create complications like wound infection, pulmonary embolism.

\section{CONCLUSION}

Indian plaster shows $77.74 \%$ efficacy in the management of malleolar fractures.

\section{REFERENCES}

1. R. O. Gorbatov, P. V. Pavlov, E. E. Malyshov. Modern operative treatment on malleolar fracture $\&$ associated consequences. 2014. June16. doi: 10.17691/stm. 2015.7. 2. 20

2. Daly PJ, Fitzgerald RH Jr, Melton LJ, Ilstrup DM. Epidemiology of ankle fractures in Rochester, Minnesota. Acta Orthop Scand. 1987; 58:539.

3. Shelton Mar vin L. Complication of fractures and dislocation of the ankle.In: Comp lications in orthopaedic surgery, Chapter 23, 3rd edn., Vol.I, edt. EPPS,Charles H, Philadelphia : J.B. Lippincott Company, 1994; 595-648pp.

4. Rohit Singh, Tamer Kamal, Nick Roulohamin et al. Ankle Fractures: A Literature review of current treatment methods. Open journal of orthopaedics. 2014; 4: 292-303.

5. Susrutha, Susrutha Samhitha Nibandha Samgraha Commentary by Dalhana edited by Vaidya Jadaviji Trikamji Published by Chaukambha Orientalia edition 2010, Nidana Sthana $15^{\text {th }}$ Chapter,4 Sloka, page no:328, PP-824.
6. Ācārya Sushrutha: Sushruthasamhita with Nibandhasangraha commentary of and Dalhana Ācārya Nyayachandrika of Gayadasa, Chaukambha orientalia, reprint edition, Chikistha sthana, 3rd chapter verse, 2014; 18: 824-416.

7. Raju G.S. Clinical evaluation of the healing of fractures with the internal and external use of murivenna. (MD Dissertation). Department of Kaya chikitsa, Ayurveda College, Trivandrum; 1980.

8. Ācārya Sushruta; Sushrutasamhita; Vaidhya Yadavji Trikamji Ācārya and Narayan Ram Ācārya, Editors; Varanasi: Chaukhambha Sanskrit Sansthana; 2013; 824:374.

9. Vipin P C. A Comprehensive study on Gulpha sandhi shareera w.s.r to sports injuries. (M.D. Dissertation). Department of Shareera Rachana, S. D. M. College of Ayurveda, Udupi; 2011.

10. Sushruta. Yadavji Trikamji Accharya, editor. Sushrutha Samhitha with Nibandha Sangraha of Dalhanacharya. $8^{\text {th }}$ ed. Varanasi: Choukambha Orientalia; 2008. Pp- 824, p- 120 .

11. Gikku Alias Benny. A randomised controlled trial in the management of gulphasandhi bhagna with asthiśrungāla bhāvita ābhāguggulu against ābhāguggulu along with standard reduction method. (M.D. Dissertation). Department of Shalyatantra, Govt. Ayurveda College, Tripunithura; 2015.

12. Martin CD, Jimenez-Andrade JM, Ghilardi JR, Mantyh PW. Organization of a unique net-like meshwork of CGRP+ sensory fibers in the mouse periosteum: implications for the generation and maintenance of bone fracture pain. Neurosci Lett. 2007;427(3): 148-52. https://doi.org/10.1016/j.neulet.2007.08.055.

13. George M.J. Evaluation of the traditional and modern methods in the management of fractures. (Ph.D. Thesis). Department of Ayurveda, Sree Sankaracharya University of Sanskrit, Kalady; 2007.

14. Sri Lakshmipati Shastri, Vidyatini Hindi commentary, edited by Sri Bhrahmashankar Shastri, Yogaratnākara Uttarardha, Bhagnachikitsa/3, $8^{\text {th }}$ ed., Chaukambha Sanskrit Sansthan, Varanasi, 2004, p190.

15. Saifudheen P. Clinical Study On Immobilisation Using Vamsha Kusha Bandha WithRaktha Chandhana Triputah Triphala And Haridra In Comparison To Plaster Of Paris Cast In The Management Of Colles' Fracture. International Ayurvedic Medical Journal \{online\} 2018 \{cited September, 2018\} Available from:http://www.iamj.in/posts/images/upload/1976_19 83.pdf. 
16. Dudhamal T S. Efficacy of Lakshadi Plaster and Laksha Guggulu in the Management of Bhagna (STable Colle's Fracture). International Journal of Ayurvedic Medicine, 2012, 3(2), 124-129.

17. Radhakrishnan S. Eco Friendly materials used in traditional buildings of Chettinadu in Tamil Nadu, India. American Journal of Sustainable Cities and Society,2014,1(30). Available online on http://www.rspublication.com/ajscs/ajsas.html

\section{Source of Support: Nil}

\section{Conflict of Interest: None Declared}

How to cite this URL: Ashik Narayan S \& Rejani H: Indian Plastering Technique In Malleolar Fractures. International Ayurvedic Medical Journal \{online\} 2020 \{cited December, 2020\} Available from: http://www.iamj.in/posts/images/upload/5207 5213.pdf 